BURCKHART, Thiago. Constitucionalismo, Direitos Humanos e Laicidade: Neopentecostalismo e Política no Brasil Contemporâneo. Revista Eletrônica Direito e Política, Programa de Pós-Graduação Stricto Sensu em Ciência Jurídica da UNIVALI, Itajaí, v.13, n.1, $1^{\circ}$ quadrimestre de 2018. Disponível em: www.univali.br/direitoepolitica - ISSN 1980-7791

\title{
CONSTITUCIONALISMO, DIREITOS HUMANOS E LAICIDADE: NEOPENTECOSTALISMO E POLÍTICA NO BRASIL CONTEMPORÂNEO
}

\author{
CONSTITUTIONALISM, HUMAN RIGHTS AND LAITY: NEOPENTECOSTALISM AND \\ POLITICS IN CONTEMPORARY BRAZIL
}

Thiago Burckhart ${ }^{1}$

SUMÁRIO: Introdução; 1. Constitucionalismo, direitos humanos e laicidade; 2. Direito, moral e política; 3. Marcos normativos na defesa da laicidade; 4. Bancada evangélica e neopentecostalismo no Brasil; 5. A atuação da bancada evangélica na PEC 181/15 como afronta ao princípio da laicidade; Considerações finais; Referências das fontes citadas.

\section{RESUMO}

Nos últimos anos e décadas houve um exponencial crescimento dos indivíduos que se autodeclaram "evangélicos" no Brasil. Para além de um fenômeno meramente religioso, os evangélicos passaram a ganhar notoriedade na esfera políticoinstitucional. Essa aproximação entre Estado e religião, entretanto, coloca em risco o princípio da laicidade que funda tanto o constitucionalismo quanto a modernidade ocidental. O risco de retrocessos se coloca na medida em que grupos religiosos tentam impor, por meio do direito e da política, sua moral. Nesse contexto, o objetivo deste artigo é de analisar, a partir da sociologia jurídica, mas com aportes da teoria constitucional, as perspectivas e desafios no que tange à laicidade no constitucionalismo brasileiro, tomando para análise a performance, mediante manobra política, da bancada evangélica frente à PEC 181/15. Para tanto o artigo divide-se em cinco partes: I - Constitucionalismo e laicidade; II - Direito, moral e política; III - Marcos normativos na defesa da laicidade; IV - Bancada evangélica e neopentecostalismo no Brasil; $\mathrm{V}$ - Performance da bancada evangélica na PEC 181/15 como uma violação ao princípio da laicidade.

Palavras-chave: Constitucionalismo; Direitos humanos; Laicidade; Neopentecostalismo; Brasil

\footnotetext{
1 Mestrando em Direito no Programa de Pós-Graduação em Direito da Universidade Federal de Santa Catarina (UFSC). Pesquisador bolsista CAPES do Grupo de Estudos em Constitucionalismo Político (UFSC). Pesquisador do Núcleo de Estudos em Constitucionalismo, Internacionalização e Cooperação (Constinter-Furb). Pesquisador do Centro Didattico Euroamericano Sulle Politiche Costituzionali (CEDEUAM, Itália-Brasil). Autor do livro "Direito, Cultura e Cidadania", Editora Prismas, 2017. Florianópolis, Santa Catarina, Brasil. E-mail: thiago.burckhart@outlook.com
} 
BURCKHART, Thiago. Constitucionalismo, Direitos Humanos e Laicidade: Neopentecostalismo e Política no Brasil Contemporâneo. Revista Eletrônica Direito e Política, Programa de Pós-Graduação Stricto Sensu em Ciência Jurídica da UNIVALI, Itajaí, v.13, n.1, $1^{\circ}$ quadrimestre de 2018. Disponível em: www.univali.br/direitoepolitica - ISSN 1980-7791

\section{ABSTRACT}

In the last decades there was an exponantial growth on the number of peoples that declare themselves as "evangelicals" in Brasil. Towards a mere religious phenomena, evangelicals gained notority in political and institutional field. This approavch between State and religion, however, puts in risk the principle of secularism that founds the constitutionalism and occidental modernity. The risk of setbacks puts itself to the extent that those religious groups try to impose, by politics and law, their own morals. In this context, this article aims to analyse, through sociology of law but with contributions of constitutional theory, the perspectives and challenges regarding to secularismo in brazilian constitutionalism, taking for analysis the performance, through an political maneuver, of the "evangelical bench" face to PEC 181/15. For this, the article is devided in five parts: I - Constitutionalism and secularismo; II - Law, morals and politics; III - Normative frameworks on the defense of secularismo; IV Evangelical brench and pentecostalism in Brazil; $V$ - Performance of evangelical brench in PEC 181/2015 as a violation of the principle of secularismo.

Keywords: Constitutionalism; Human rights; Secularism; Neopentecostalism; Brazil

\section{INTRODUÇÃO}

Nos últimos anos e décadas houve um exponencial crescimento do neopentecostalismo no cenário religioso brasileiro. Desde o ano de 2013 as denominações religiosas pentecostais se colocam, em percentuais, como aquelas que mais crescem em todo o país. Para além de um fenômeno meramente religioso, entretanto, paralelo a isso houve um processo de empoderamento político destes grupos, que passaram a galgar cargos no poder executivo e legislativo, constituindo partidos políticos e ocupando atualmente um significativo espaço no Congresso Nacional e em demais cargos de destaque na política brasileira.

Tal situação acarreta impacto direto nas decisões políticas emanadas destas entidades. Trata-se da tentativa de imposição da moral religiosa por meio da política ordinária, influenciando diretamente a construção e modificação do direito. Esse fenômeno negligencia um dos pilares do Estado Democrático de Direito, qual seja a laicidade. A separação entre Estado e religião e liberdade religiosa são o que constitui o ideário da modernidade, de modo que o secularismo é um dos elementos que fundam a ordem moderna e o próprio constitucionalismo no final do século XVIII. O constitucionalismo brasileiro, entretanto, convive com um distanciamento claro entre texto e contexto tendo por desafio colmar esta 
BURCKHART, Thiago. Constitucionalismo, Direitos Humanos e Laicidade: Neopentecostalismo e Política no Brasil Contemporâneo. Revista Eletrônica Direito e Política, Programa de Pós-Graduação Stricto Sensu em Ciência Jurídica da UNIVALI, Itajaí, v.13, n.1, $1^{\circ}$ quadrimestre de 2018. Disponível em: www.univali.br/direitoepolitica - ISSN 1980-7791

distância. Nesse contexto, a influência de grupos religiosos na política, em que estes reivindicam a imposição de sua própria visão de mundo, traz consigo a possibilidade de retrocessos significativos para a laicidade no Brasil.

Tomando isso em consideração, torna-se oportuno refletir sobre a influência dos grupos políticos neopentecostais, que se autointitulam como "bancada evangélica" no atual estágio da política e constitucionalismo do Brasil. Nesse sentido, este artigo tem por objetivo analisar a atuação da bancada evangélica e as possibilidades de retrocesso no constitucionalismo brasileiro, tomando como exemplo a performance da bancada evangélica na recente discussão da PEC 181/15, realizada em 2017, como uma violação ao princípio da laicidade. Procurase fornecer subsídios teóricos para a discussão desde a sociologia jurídica, mas em abordagem comprometida com a teoria constitucional. Para tanto, o artigo dividese em cinco partes: I - Constitucionalismo e laicidade; II - Direito, moral e política; III - Marcos normativos na defesa da laicidade; IV - Bancada evangélica e neopentecostalismo no Brasil; V - Performance da bancada evangélica na PEC 181/15 como uma violação ao princípio da laicidade.

\section{CONSTITUCIONALISMO, DIREITOS HUMANOS E LAICIDADE}

O constitucionalismo, enquanto ideal moderno, é resultado das revoluções liberais do século XVIII. A Revolução Francesa e americana são resultado de um processo de firmação de princípios e valores que se projetam na ordem política ainda hodiernamente. O constitucionalismo firma-se na necessidade de 1) garantir formalmente e materialmente os direitos dos cidadãos, e 2) criar limites ao poderio do Estado, ou seja, formas de limitação ao poder Estatal, 3) por meio da Constituição em sua forma escrita². Como todo o processo dialógico, o constitucionalismo passou por diversas evoluções aquisitivas ao longo do século XIX, XX e XXI, de modo que a literatura jurídica categorizam-nas como

${ }^{2}$ Cfe. CANOTILHO, José Joaquim Gomes. Direito Constitucional e Teoria da Constituição. 7a Ed. Coimbra : Almedina, 2011. 
BURCKHART, Thiago. Constitucionalismo, Direitos Humanos e Laicidade: Neopentecostalismo e Política no Brasil Contemporâneo. Revista Eletrônica Direito e Política, Programa de Pós-Graduação Stricto Sensu em Ciência Jurídica da UNIVALI, Itajaí, v.13, n.1, $1^{\circ}$ quadrimestre de 2018. Disponível em: www.univali.br/direitoepolitica - ISSN 1980-7791

constitucionalismo liberal, constitucionalismo social e constitucionalismo solidário, seguindo o lema da Revolução Francesa³.

Da necessidade de garantir os direitos do cidadão, os direitos humanos também nascem num processo de atrelamento ao constitucionalismo. Nascem, em um primeiro momento, como um leque de liberdades fundamentais que garantem a limitação do Estado absolutista e um maior grau de liberdade para os cidadãos ${ }^{4}$. Os direitos humanos passam pelo mesmo processo de evolução aquisitiva do constitucionalismo moderno, e se firmam como ideário revolucionário ainda atualmente. Tanto o constitucionalismo quanto os direitos humanos nascem no período de consolidação da modernidade ${ }^{5}$, e podem ser considerados pilares que fundam a racionalidade moderna ${ }^{6}$, sob os signos da liberdade e igualdade.

A firmação de um ideário de Estado distante do modelo absolutista, no qual o soberano era um "correspondente de deus na terra", implicava na firmação de outro princípio fundamental da modernidade, a laicidade. É com o advento da modernidade que nasce a teoria da secularização coligada à teoria do republicanismo. Em efeito, desenha-se um contexto no Ocidente em que se anunciava o "fim da religião"7, marcado pelo processo de laicização do Estado. 0 Estado laico implica, à primeira vista para muitos autores, "a desvinculação entre aparato estatal e instituições religiosas", mas também "um ideal de eliminação de toda referência a valores e conteúdos religiosos nas áreas reguladas por leis civis,

\footnotetext{
3 BOBBIO, Norberto. A era dos direitos. Rio de Janeiro : Elsevier, 2004.

${ }^{4}$ Evidentemente, a noção de cidadão era restrita a uma "estética do poder". Para aprofundamentos, ver: BURCKHART, Thiago. Direito, Cultura e Cidadania. Curitiba : Prismas, 2017. Para aprofundamentos, ver: DULCE, Maria José Fariñas. Democracia y pluralismo: una mirada hacia la emancipación. Madrid : Dykinson, 2014.

5 Na perspectiva de Enrique Dussel, o primeiro ciclo da modernidade inicia com o "descobrimento" da América pelos Europeus em 1492. Desde então, a modernidade passou a paulatinamente se consolidar, sendo as revoluções liberais do século XVIII o fenômeno que consolidou o pensamento moderno no ocidente. Para aprofundamentos, ver: DUSSEL, Enrique. 1492. El encubrimiento del otro: hacie el orígen del mito de la modernidad. La Paz : CLACSO, 1994.

6 Para aprofundamentos, ver: SANTOS, Boaventura de Sousa. Pelas mãos de Alice: o social e o político na pós-modernidade. 7a Ed. Porto : Afrontamentos, 1999.

${ }^{7}$ Cfe. GIUMBELLI, Emerson. Religião, Estado, modernidade: notas a propósito de fatos provisórios. Estudos Avançados USP. São Paulo, v. 52, n. 52, 2004, p. 48.
} 
BURCKHART, Thiago. Constitucionalismo, Direitos Humanos e Laicidade: Neopentecostalismo e Política no Brasil Contemporâneo. Revista Eletrônica Direito e Política, Programa de Pós-Graduação Stricto Sensu em Ciência Jurídica da UNIVALI, Itajaí, v.13, n.1, $1^{\circ}$ quadrimestre de 2018. Disponível em: www.univali.br/direitoepolitica - ISSN 1980-7791

e por conseguinte, do próprio espaço público"8. Religião passou a ser, desde então, uma matéria de foro íntimo.

Em termos conceituais, Norberto Bobbio, Nicolà Matteucci e Gianfranco Pasquino realizam uma diferenciação entre os termos laicidade e secularização. Para eles, a secularização, compreendida em termos sociológicos, caracteriza um processo de transição das sociedades tradicionais, rurais e fechadas para sociedades industriais onde a há uma redução do peso da religião no controle social, correspondendo ao que Max Weber ${ }^{9}$ chama de "dessacralização" da sociedade moderna ${ }^{10}$. A laicidade, portanto, é um fenômeno atrelado ao processo de secularização, na medida em que os Estados modernos passam a se distanciar a sua esfera pública daquela religiosa. Também há que se mencionar que o Estado laico, aquele que aplica o princípio da laicidade, não se confunde com um "Estado contra as religiões" comum, por exemplo, nas Repúblicas Socialistas do século XX - aquele que este repudia e vocifera contra todas as formas de manifestação religiosa. O Estado laico preza pela liberdade religiosa e a possibilidade de cada pessoa professar a sua fé como matéria de foro íntimo.

Também há que se distinguir as noções de laicidade e laicismo. Para o pesquisador português António Matos Ferreira, o termo laicismo "surge como um conglomerado de tendências que, por diversas vias e de forma voluntarista, pretendem estimular o retraimento ou desaparecimento da religião enquanto tal", ou seja, "o laicismo surge associado ao esforço de se contrariar as marcas religiosas e a presença das instituições religiosas na sociedade"11. Por isso, o laicismo se apresenta como totalitário o que é o exato contrário da laicidade. A laicidade visa construir uma esfera de tolerância com relação às diferentes cosmovisões religiosas, sem entretanto 1) favorecer, promover ou subvencionar religiões, 2) obstaculizar ou discriminar religiões, 3) e sem tomar a religião como orientação para a atuação do

\footnotetext{
8 GIUMBELLI, Emerson. Religião, Estado, modernidade, p. 48.

9 WEBER, Max. Economia e sociedade. Vol I. $4^{a}$ Ed. Brasília : Editora da Universidade de Brasília, 2000.

10 BOBBIO, Norberto; MATTEUCCI, Nicolà; PASQUINI, Gianfranco. Dicionário de Política. Vol I. $11^{a}$ Ed. Brasília : Editora Universidade de Brasília, 1998.

11 FERREIRA, António Matos. Laicismo ideológico e laicidade: entre a ideia de tolerância e a tentação totalitária. Revista Theologica, 2a série, n. 39, v. 2, 2004, p. 318.
} 
BURCKHART, Thiago. Constitucionalismo, Direitos Humanos e Laicidade: Neopentecostalismo e Política no Brasil Contemporâneo. Revista Eletrônica Direito e Política, Programa de Pós-Graduação Stricto Sensu em Ciência Jurídica da UNIVALI, Itajaí, v.13, n.1, $1^{\circ}$ quadrimestre de 2018. Disponível em: www.univali.br/direitoepolitica - ISSN 1980-7791

Estado $^{12}$. Na perspectiva de Ferreira, a laicidade pretende limitar as formas de dominação que impeçam o desenvolvimento e o exercício da liberdade individual ${ }^{13}$.

Nesse contexto, a laicidade e a liberdade religiosa passaram a ser projetados como princípios que fundam uma nova sociedade e uma nova ordem política. Trata-se de uma revolução e inversão nos ideários até então vigentes. A liberdade religiosa nasce e projeta-se, ao longo da modernidade, como liberdade fundamental, tendo sido uma questão abordada por diversos pensadores da época. John Locke, em sua Carta Acerca da Tolerância, advoga no sentido de construir um espaço de respeito para com os defensores de opiniões opostas acerca de temas religiosos. Calcado numa dinâmica de pensamento liberal, Locke foi fundamental para a construção do secularismo e do processo de laicização do Estado, que implica a não imposição por parte do Estado de uma religião "oficial"14.

Alain Touraine explica que a modernidade e a democracia somente foram possíveis em razão do processo de secularização do espaço público. Apesar de entender que "as relações entre a religião e a democracia são sempre complexas e, até mesmo,

\footnotetext{
12 Essa categorização extrai-se do voto do Ministro Roberto Barroso do Supremo Tribunal Federal na Ação Direta de Inconstitucionalidade n. 4.439/DF, na qual o Supremo Tribunal Federal Federal posicionou-se sobre a possibilidade do ensino confessional em escolas públicas, tendo o referido Ministro atuado como Relator do caso. BARROSO, Luís Roberto. Ação Direta de Inconstitucionalidade 4.439/DF (Voto). Tribunal Pleno do Supremo Tribunal Federal, 2016, p. 16. Barroso inspira-se na teoria de Martha Nussbaum para articular essa categorização, sobretudo a partir do livro: NUSSBAUM, Martha. Liberty of conscience: in defense of America's tradition of religious equality. Cambridge : Harvard University Press, 2008, p. 226-227.

13 FERREIRA, António Matos. Laicismo ideológico e laicidade, p. 319.

14 Nesse sentido, "Cette dissociation du regnum hominis vis-à-vis de la loi divine ne s'est pas incarnée partout, cependant, dans la même figure institutionnelle. Deux grands modèles se sont progressivement imposés. Une partie des pays européens (certains pays scandinaves comme la Suède - jusqu'en 2000 -, la Norvège, le Danemark, mais l'Angleterre) ont, tout en affirmant la souveraineté du politique, maintenu le lien entre l'Etat et l'Eglise dominante. On a pu parler de système de «confessionnalité». L'alliance ici ne s'est pas faite avec l'Eglise catholique, mais avec I'Eglise protestante, anglicane ou luthérienne, dont le propre est d'avoir accepté la prévalence du pouvoir politique, plus aisément que le catholicisme romain, demeuré attaché, au moins jusqu'à Vatican II, à la théologie de la potestas indirecta. Une autre catégorie a opté pour le régime de «séparation», en refusant l'idée de religion d'Etat. La séparation peut être souple, capable donc de ménager des espaces de coopération entre les Eglises et l'autorité politique, comme en Belgique ou en Allemagne. Elle peut être stricte également, comme au Portugal dans les années 1910, en Espagne dans les années 1930, ou, en France, avec le modèle juridique issu des années 1880-1905." PORTIER, Philippe. Nouvelle modernité, nouvelle laicité. La Republique française face ao religieux (1880-2009). Estudos de Religião, v. 25, n. 41, jul-dez 2011, pp. 44.
} 
BURCKHART, Thiago. Constitucionalismo, Direitos Humanos e Laicidade: Neopentecostalismo e Política no Brasil Contemporâneo. Revista Eletrônica Direito e Política, Programa de Pós-Graduação Stricto Sensu em Ciência Jurídica da UNIVALI, Itajaí, v.13, n.1, $1^{\circ}$ quadrimestre de 2018. Disponível em: www.univali.br/direitoepolitica - ISSN 1980-7791

contraditórias" $^{15}$, compreendendo que nem em todos os aspectos a religião é incompatível com a democracia, Touraine afirma que a subordinação da ação política a um princípio não político ou garantia metapolítica, quer seja um deus ou uma terra, uma língua ou uma raça, é incompatível com a democracia ${ }^{16}$. N esse contexto, a democracia moderna, no pensamento de Touraine, deve ser compreendida como um constante processo de libertação e emancipação dos sujeito ${ }^{17}$. Nesse sentido, o processo revolucionário de fundação da liberdade, como afirma Hannah Arednt, busca edificar uma nova perspectiva de civilização, na qual se reconhece o povo como detentor do poder soberano ${ }^{18}$. Essa ideia encontra-se atrelada e sustentada tanto no constitucionalismo quanto nos direitos humanos, sendo o elo que une tanto a Revolução francesa quanto a Revolução americana.

A laicidade edifica-se nesse contexto e passa a assumir diferentes conotações a depender da área geográfica em que é edificada. No Brasil, por exemplo, a histórica relação entre as elites políticas e econômicas com o cristianismo é um aspecto que dificulta sobremaneira a concretização deste princípio. O aumento exponencial dos evangélicos ${ }^{19}$ e sua projeção política nas diversas instâncias do poder são outro aspecto que dificulta a efetivação da laicidade enquanto componente central da República. A laicidade, portanto, apesar de ser um princípio

15 TOURAINE, Alain. O que é democracia? Tradução de Guilherme João de Freitas Teixeira. Petrópolis : Editora Vozes, 1996, p. 235.

16 TOURAINE, Alain. O que é democracia? P. 97

17 Cfe. TOURAINE, Alain. O que é democracia? Num contexto marcado pela crescente bipolaridade entre o mercado e as identidades entre a liberalização econômica e os (neo)comunitarismos, Touraine entende que a democracia é a chave para colmar as distâncias entre os indivíduos, a partir de seu processo de compreensão como sujeito, e portanto, como ator de sua vida e de suas escolhas, bem como estando consciente de sua posição no mundo. A ação democrática conduz a sociedade na direção de sua emancipação, que é essencialmente individual, para a construção de uma coletividade consciente. Para aprofundamentos, ver: TOURAINE, Alain. O que é democracia?; e TOURAINE, Alain. Poderemos viver juntos? Iguais e diferentes. Tradução de Jaime Al. Clasen e Ephrim F. Alves. Petrópolis : Editora Vozes, 1999.

18 ARENDT, Hannah. Sobre a revolução. São Paulo : Companhia das Letras, 2011, p. 276.

19 Neste artigo o termo evangélico é utilizado para se referir aos praticantes do as denominações religiosas cristãs denominadas pela sociologia da religião de neopentecostais, vertente pentecostal que se prolifera a partir da década de 1970 no Brasil, com o surgimento da Igreja Universal do Reino de Deus e Internacional da Graça de Deus. Esse grupo é caracterizado por uma interpretação gramatical dos textos bíblicos, guerra contra o "diabo" e teologia da prosperidade. Para aprofundamentos, ver: ROSAS, Nina. O desenvolvimento do neopentecostalismo brasileiro. In: XI Simpósio Nacional da Associação Brasileira de História das Religiões. Goiânia, 2009; e MARIANO, Ricardo. Neopentecostais: sociologia do novo pentecostalismo no Brasil. Ed. Loyola: São Paulo, 2005. 
BURCKHART, Thiago. Constitucionalismo, Direitos Humanos e Laicidade: Neopentecostalismo e Política no Brasil Contemporâneo. Revista Eletrônica Direito e Política, Programa de Pós-Graduação Stricto Sensu em Ciência Jurídica da UNIVALI, Itajaí, v.13, n.1, $1^{\circ}$ quadrimestre de 2018. Disponível em: www.univali.br/direitoepolitica - ISSN 1980-7791

que edifica o constitucionalismo, os direitos humanos e a modernidade, não é ainda tratado como consenso em diversas partes do mundo ${ }^{20}$. A influência de religiões no espaço político ainda é evidente em diversos países do mundo mesmo em países europeus e do mundo ocidental - evidenciando o grande desafio, ainda presente no contemporâneo, que é a concretização deste direito.

\section{DIREITO, MORAL E POLÍTICA}

A discussão que toca à relação entre direito e moral permeia um longo caminho na história da filosofia e teoria do direito, tendo provocado repercussões diretas ainda hodiernamente. É possível encontrar diferentes visões sobre a relação que há entre essas categorias, contudo, para compreender essa relação torna-se primeiramente necessário analisar o que é o fenômeno da moral. Nesse artigo, entende-se por moral como "o conjunto de regras de conduta assumidas livre e conscientemente pelos indivíduos, com a finalidade de organizar as relações interpessoais segundo os valores do bem e do mal"21. Trata-se, portanto, de um padrão de conduta estabelecido social e politicamente que regula as ações das pessoas de uma comunidade ou sociedade.

No âmbito desse conceito ainda existe uma subdivisão: a moral heterônoma e a autônoma. A moral heterônoma (hetero = outro, diferente; nomos = lei) diz respeito ao comportamento regulado pelo meio social, ou seja, aquele que é consenso entre a sociedade ou comunidade e imposto a todos os grupos (ou grupo) por meio da ideologia. A moral autônoma (auto = próprio) diz respeito à tomada de consciência por parte do indivíduo de suas ações e condutas, de modo a agir partindo de sua própria construção autônoma e reflexiva sobre o que é "bom" ou "ruim", sem haver necessariamente a interferência de imposições sociais nessa tomada de decisão. Contudo, para que se alcance a autonomia moral é necessário

\footnotetext{
20 Um claro exemplo é o mundo muçulmano, no qual Edward Said uma vez afirmou que este necessita de uma revolução de secularismo. SAID, Edward. Orientalismo: o oriente como invenção do ocidente. São Paulo : Companhia das Letras, 1990.

${ }^{21}$ ARANHA, Maria Lúcia de Arruda; MARTINS, Maria Helena Pires. Temas de Filosofia. Editora Moderna : São Paulo, 2005, p. 216 - 218. Para aprofundamentos, ver: NIETZSCHE, Friedrich. Genealogia da moral: uma polêmica. Tradução, notas e posfácio de Paulo César de Souza. São Paulo : Companhia das Letras, 2009.
} 
BURCKHART, Thiago. Constitucionalismo, Direitos Humanos e Laicidade: Neopentecostalismo e Política no Brasil Contemporâneo. Revista Eletrônica Direito e Política, Programa de Pós-Graduação Stricto Sensu em Ciência Jurídica da UNIVALI, Itajaí, v.13, n.1, $1^{\circ}$ quadrimestre de 2018. Disponível em: www.univali.br/direitoepolitica - ISSN 1980-7791

formar-se como sujeito moral, como mandante de suas próprias ações ${ }^{22}$, reconhecendo-se "o outro como um eu-outro"23.

Nesse sentido, a moral distingue-se da ética. A ética, ou filosofia moral, é uma reflexão crítica sobre a moral, ou seja, sobre as ações e condutas de cada pessoa. É uma parte da filosofia encarregada de refletir sobre as condutas individuais e/ou coletivas a partir de valores éticos que "se oferecem, portanto, como expressão e garantia de nossa condição de seres humanos ou de sujeitos racionais e agentes livres, proibindo moralmente a violência"24. A ética é, dessa forma, normativa, pois determina permissões e proibições que visam impor limites e controles ao risco permanente de violência, resguardando o valor da dignidade da pessoa humana.

Nessa perspectiva, a moral é um importante instrumento para regular as relações sociais do cotidiano, desde que ela mesma se coloque em um confronto entre a moral constituída (isto é, os valores herdados) e a moral constituinte, representada pela crítica aos valores ultrapassados e pela gestação de novos parâmetros de avaliação e conduta. Essa crítica, ou seja a ética, é necessária para uma não-alienação do sujeito em face à dinamicidade social, de modo que o mesmo não torne-se "moralista". Diferente do "sujeito ético/moral", aquele que reflete sobre suas ações, é o "moralista" que tenta impor aquilo que faz, aquilo que pensa que é correto segundo seu julgamento de valor aos outros ${ }^{25}$.

22 "Alcançar a autonomia, porém, não é um processo automático, pois muitas pessoas nunca conseguirão sair do mundo da heteronomia. Para tanto, será preciso formar o sujeito moral, num esforço de descentração para superar o egocentrismo infantil: mediado pelo outro, saímos de nós mesmos". ARANHA, Maria Lúcia de Arruda; MARTINS, Maria Helena Pires. Temas de Filosofia, p. 217.

${ }^{23}$ Referência à obra de Narciso, de Caravaggio, 1598-99, pela qual retrata "o mito grego de Narciso personagem que morre enamorado pela própria imagem refletida na água, representa aqueles que não conseguem sair de si mesmos e descobrir a alteridade: ser moral é reconhecer o outro como um outro-eu". ARANHA, Maria Lúcia de Arruda; MARTINS, Maria Helena Pires. Temas de Filosofia, p. 216.

${ }^{24}$ CHAUÍ, Marilena. Filosofia. São Paulo : Editora Ática, 2008, p. 208.

25 De acordo com André Comte-Sponville "a moral responde à pergunta: 'o que devo fazer?'. É o conjunto dos meus deveres, em outras palavras, dos imperativos que reconheço legítimos - mesmo que, às vezes, como todo mundo, eu os viole. É a lei que imponho a mim mesmo, ou que deveria me impor, independentemente do olhar do outro e de qualquer sanção ou recompensa. 'O que devo fazer?' e não: 'o que os outros devem fazer?' é o que distingue a moral do moralismo". ARANHA, Maria Lúcia de Arruda; MARTINS, Maria Helena Pires. Temas de Filosofia, p. 218. 
BURCKHART, Thiago. Constitucionalismo, Direitos Humanos e Laicidade: Neopentecostalismo e Política no Brasil Contemporâneo. Revista Eletrônica Direito e Política, Programa de Pós-Graduação Stricto Sensu em Ciência Jurídica da UNIVALI, Itajaí, v.13, n.1, $1^{\circ}$ quadrimestre de 2018. Disponível em: www.univali.br/direitoepolitica - ISSN 1980-7791

No entanto, apesar de ética e moral serem normativas, elas não produzem efeito vinculante, de modo que não são coercitivas ao sujeito que as segue, sua sanção pelo seu descumprimento é informal. Essa é uma das características que mais claramente difere o direito da moral, haja vista que o direito é um conjunto de normas, valores e princípios emanados pela política - Estado - que são coercitivas e que visam, regular as relações sociais, políticas, econômicas, dentre outras que se apresentem como "questões jurídicas". Dessa forma, observa-se que o direito encontra fulcro na moral e na ética, na medida em que é edificando com base na cultura de determinado povo, mas com elas não se confunde, pois o direito é dotado de coercitividade. Da mesma forma, o direito também produz influência na moral e na ética ${ }^{26}$.

Nesse sentido, a discussão que se coloca para a dicotomia entre moral e direito é a possibilidade de legitimidade pela legalidade. Jürgen Habermas aponta que a legalidade do direito é legítima em virtude da racionalidade imposta ao mesmo, ou seja, a racionalidade jurídica é o fundamento da moral. Dessa forma, Habermas critica a visão positivista de direito e a noção de que o direito é algo alheio à moral, concepção defendida por Max Weber pela qual entende que o direito não pode confundir-se com a moral e sua assimilação caracteriza a perda de sua formalidade, e consequentemente a perda de seus fins teleológicos. Habermas defende a legitimação da legalidade e para tanto torna-se necessário uma aceitação moral dos preceitos legais básicos 27 .

\footnotetext{
26 "Podemos [...] encontrar casos de contradição entre as normas jurídicas e morais. Exemplos: matar um sargento ditador (o famoso tiranicídio) pode ser um ato de elevação moral que muitos admiram; mas, ao mesmo tempo, pode ser um grave delito. Demitir por justa causa um funcionário que tem cinco filhos e mulher doente pode ser moralmente repreensível e, ao mesmo tempo, juridicamente permitido". DIMOULIS, Dimitri. Manual de Introdução do Direito. 3a Ed. São Paulo : Editora Revista dos Tribunais, 2010, p. 62.

27 Para aprofundamentos, ver: HABERMAS, Jürgen. Direito e Moral. Tradução de Sandra Luppert. Instituto Piaget : Lisboa, 1992. Neste livro, Habermas faz uma crítica à Max Weber quanto à sua concepção positivista e formalista do direito pela qual concebia que "o direito moderno tem, obrigatoriamente, que poder legitimar o poder político legalmente exercido, exclusivamente, com base em algumas características formais próprias" (p. 14). Além disso, de acordo com Weber "as exigências de justiça material penetram no meio do direito e destroem a sua racionalidade formal" (p. 17). Essa concepção, como muito bem assinala Habermas, foi abalada pelo nascimento do Estado Social, onde a racionalidade essencialmente formalista do direito foi, de certo modo, quebrada. Contudo, observa-se que, sobretudo a partir da Segunda Guerra Mundial, com a Declaração Universal dos Direitos Humanos de 1948, a criação do Sistema Internacional de Proteção dos Direitos Humanos e com a positivação dos princípios da dignidade da pessoa humana em diferentes constituições em todo o globo, a moral/ética passam a influenciar a construção das normas jurídicas de forma mais
} 
BURCKHART, Thiago. Constitucionalismo, Direitos Humanos e Laicidade: Neopentecostalismo e Política no Brasil Contemporâneo. Revista Eletrônica Direito e Política, Programa de Pós-Graduação Stricto Sensu em Ciência Jurídica da UNIVALI, Itajaí, v.13, n.1, $1^{\circ}$ quadrimestre de 2018. Disponível em: www.univali.br/direitoepolitica - ISSN 1980-7791

A crítica de Habermas a Weber é no sentido deste último conceber o direito de modo positivista e formalista, afastando do mesmo a moral o que o aproxima da "teoria pura do direito" de Hans Kelsen, que idealizava uma interpretação do direito sem a interferência de outros campos de estudo como a política, a sociologia, a ética, a moral, entre outros, formando um quadro lógico do direito dotado de racionalidade própria 28 . Nesse sentido, Habermas afirma:

Legalidade pode gerar legitimidade, unicamente na medida em que a ordem jurídica reage de modo reflexivo à necessidade de justificação, que nasce com um direito que se torna positivo, precisamente na medida em que procedimentos jurídicos de decisão que facultam os discursos morais são institucionalizados ${ }^{29}$.

Nesse sentido, os discursos morais não podem ser simplesmente incorporados ao ordenamento jurídico. Se forem, ocorre a possibilidade do direito torna-se "moralista", ou seja, um ordenamento jurídico que não preza pela pluralidade e pelo reconhecimento da diferença, mas impõe padrões de comportamento aos indivíduos em sua dinâmica de vida privada. Para que haja aproximação entre o direito e a moral, torna-se necessário que a moral passe por um "filtro ético", ou seja, por um processo de reflexão crítica, realizada tanto pelos representantes políticos quanto pela sociedade civil, quanto aos efeitos de determinada legislação, de modo que a legitimidade do direito se paute na ética e não em uma moral heterônoma.

Nesse mesmo sentido, mesmo tendo em vista que a política é um campo de "agonismos"30, cabe ressaltar que a concepção de política moderna edificada sob

nítida, sobretudo em virtude das sistemáticas violações de direito ocorridas na Segunda Guerra Mundial (e no caso da América Latina, nas ditaduras militares dos anos 1970 e 1980). Nesse sentido, Habermas afirma que hodiernamente a influência da moral no direito, dá-se no plano dos princípios. Como bem afirma, no que tange à Constituição "apresenta-se, atualmente, como um todo dinâmico, onde os conflitos entre bem individual e bem público, tem que ser compensados, respectivamente, ad hoc, á luz de princípios supremos constitucionais e de uma compreensão holista da constituição" (p. 48).

28 Para aprofundamentos, ver: KELSEN, Hans. Teoria pura do direito. São Paulo: Revista dos Tribunais, 2a ed., 2002.

29 HABERMAS, Jürgen. Direito e Moral, p. 57.

30 Aqui faz-se referência a Chantal Mouffe, MOUFFE, Chantal. El retorno de lo político: comunidade, ciudadanía, pluralismo, democracia radical. Barcelona : Ediciones Paidós Ibérica, 1999. 
BURCKHART, Thiago. Constitucionalismo, Direitos Humanos e Laicidade: Neopentecostalismo e Política no Brasil Contemporâneo. Revista Eletrônica Direito e Política, Programa de Pós-Graduação Stricto Sensu em Ciência Jurídica da UNIVALI, Itajaí, v.13, n.1, $1^{\circ}$ quadrimestre de 2018. Disponível em: www.univali.br/direitoepolitica - ISSN 1980-7791

o prisma do constitucionalismo e dos direitos humanos impõe restrições à atuação de representantes em diversos âmbitos. A garantia formal dos direitos do cidadãos - posteriormente categorizados como "direitos fundamentais", pela primeira vez na Constituição de Weimar de $1919^{31}$ - implica em restrições à atuação de representantes políticos. Estes não podem propor projetos de leis, por exemplo, que tenham por objetivo desqualificar, negar ou inviabilizar os direitos fundamentais / humanos.

Nesse sentido, a postura de uma neutralidade do Estado em face das religiões não implica na proibição ou no necessário afastamento das interferências filosóficas e ideológicas do cenário político. Mas implica na garantia material da laicidade na medida em que o Estado não tenha sua atuação orientada ou condicionada por religiões ou que venha a favorecê-las.

A política não pode assumir uma dimensão fundamentalista, calcada em uma única visão de mundo - considerada correta -, em que se nega a pluralidade e as diferentes perspectivas que conformam a sociedade e as relações sociais. $O$ fundamentalismo político, sendo este um novo fenômeno no século XXI, encontra fulcro na medida que sua racionalidade se assemelha e se aproxima à racionalidade religiosa. O "renascimento das religiões" e de um espírito religioso no final do século XX e século XXI guiadas por uma razão fundamentalista põe em xeque a promessa moderna de concretização da democracia. Na medida em que essas epistemologias se projetam politicamente a democracia é paulatinamente negada e extirpada. Em efeito, o exato contrário do pensamento democrático hodierno é o fundamentalismo, seja ele político, religioso, econômico, cultural, ou qualquer outro. Ser democrata atualmente é estar ciente da necessidade de descontruir e deslegitimar o fundamentalismo.

31 Cfe RODOTÀ, Stefano. Diritto e giustizia: interroghiamo la Costituzione. Napoli : La Scuola do Pitagora editrice, 2016, pp. 29-30. 
BURCKHART, Thiago. Constitucionalismo, Direitos Humanos e Laicidade: Neopentecostalismo e Política no Brasil Contemporâneo. Revista Eletrônica Direito e Política, Programa de Pós-Graduação Stricto Sensu em Ciência Jurídica da UNIVALI, Itajaí, v.13, n.1, $1^{\circ}$ quadrimestre de 2018. Disponível em: www.univali.br/direitoepolitica - ISSN 1980-7791

\section{MARCOS NORMATIVOS NA DEFESA DA LAICIDADE}

A religião é uma instituição que marca a dinâmica da evolução das sociedades ao longo da história. É difícil de encontrar sociedades que não tiveram nenhum tipo de expressão religiosa (ou mesmo filosófica) e que não se projetasse em suas respectivas instituições ${ }^{32}$. Nesse sentido, a história de formação tanto cultural quanto política do Brasil também foi permeada pela influência direta do cristianismo, que viveu um grande momento de expansão quando da colonização da América Latina entre os séculos XV ao XVIII. O processo de secularização do Estado foi acompanhado pela secularização do direito, como evidencia Simone Goyard-Fabre ${ }^{33}$. Muito timidamente desde o século XVI, autores como Jean Bodin exerceram uma significativa importância no reconhecimento do direito com aspectos de cientificidade, negando a sua dimensão teológica.

É neste contexto, portanto, que os primeiros documentos em defesa da laicidade foram produzidos. A Declaração Universal dos Direitos do Homem e do Cidadão de 1789 foi um grande marco na positivação desta perspectiva, ao estabelecer em seu artigo $10^{\circ}$ que "ninguém pode ser inquietado pelas suas opiniões, incluindo opiniões religiosas, contando com a manifestação delas não perturbe a ordem pública estabelecida pela lei". Apesar de incipiente, a Declaração sela a aspiração pela construção de um Estado Laico, onde haja efetivamente o respeito às diferenças religiosas, partindo da afirmação do antropocentrismo e da tolerância enquanto valor e ideal a ser praticado pelo Estado e sociedade civil.

Em efeito, as evoluções aquisitivas dos direitos humanos e do constitucionalismo democrático em todo o globo, como atesta Bruce Ackerman ${ }^{34}$, permitiram uma gradual e paulatina abertura leque de direitos, prevendo a laicidade como princípio

32 Nesse sentido, Victor Hellern, Henry Notaker e Jostein Gaarder afirmam que "Não existe nenhuma raça ou tribo de que haja registro que não tenha tido algum tipo de religião". GAADER, Jostein; HELLERN, Victor; NOTAKER, Henry. O livro das religiões. 7a Ed. Tradução de Isa Mara Lando. São Paulo : Companhia das Letras, 2000, p. 08.

33 GOYARD-FABRE, Simone. Os fundamentos da ordem jurídica. São Paulo : Martins Fontes, 2002.

34 Para aprofundamentos, ver: ACKERMAN, Bruce. The rise of world constitutionalism. Yale Law School, 1997. 
BURCKHART, Thiago. Constitucionalismo, Direitos Humanos e Laicidade: Neopentecostalismo e Política no Brasil Contemporâneo. Revista Eletrônica Direito e Política, Programa de Pós-Graduação Stricto Sensu em Ciência Jurídica da UNIVALI, Itajaí, v.13, n.1, $1^{\circ}$ quadrimestre de 2018. Disponível em: www.univali.br/direitoepolitica - ISSN 1980-7791

fundante de diversos Estados. O Direito Internacional dos Direitos Humanos ${ }^{35}$, um ramo do direito que passou a se especializar a partir do final da Segunda Guerra Mundial, traz em seu bojo uma série de documentos que visam garantir a liberdade religiosa. Nesse sentido, o art. 18 da Declaração Universal dos Direitos Humanos de 1948 estabelece que todo ser humano possui direito à liberdade de religião.

Em razão da Declaração Universal dos Direitos Humanos ${ }^{36}$ ter sido promulgada por meio de uma Resolução da Organização das Nações Unidas, o seu texto passou por um processo de juridicização por meio de dois pactos: Pacto Internacional sobre Direitos Civis e Políticos, e Pacto Internacional sobre Direitos Econômicos, Sociais e Culturais $(1966)^{37}$. O direito à liberdade religiosa está inscrito no art. 18 do Pacto Internacional sobre Direitos Civis e Políticos, que implica tanto a liberdade de ter ou adotar uma religião ou crença de sua escolha e professá-la, bem como o direito de não ser submetido a medidas coercitivas que possam restringir sua liberdade de ter ou de adotar uma religião ou crença ${ }^{38}$.

Ainda na esfera internacional, a recente Declaration Univerelle sur la laïcité au XXIe siècle ${ }^{39}(2005)$, escrita pelo Congresso francês se posiciona como um novo

35 Para aprofundamentos, ver: CANÇADO TRINDADE, Antônio Augusto. Tratado de Direito Internacional dos Direitos Humanos. Vol I ,Porto Alegre : Sergio Fabris Editor, 2003.

36 Muitos autores identificam a referida declaração como resultado de um processo também religioso de cunho cristão. No entanto, neste artigo entende-se que a Declaração Universal dos Direitos Humanos é resultado de um processo de discussão essencialmente política, de modo que sua fundamentação também é essencialmente política e não religiosa. Nessa esteira, é pelo fato de a Declaração tomar como referencial epistemológico e ideológico o liberalismo político ocidental que lideranças políticas de países árabes, africanos e orientais, por exemplo, contestam uma série de direitos nela elencados, já que seus sistemas políticos são baseados em outras bases epistemológicas e ideológicas. Para aprofundamentos, ver: PINZANI, Alessandro. A cara de Janus dos direitos humanos: os direitos humanos entre política e moral. In. LUNARDI, Giovanni; SECCO, Marcio (Orgs.). Fundamentação Filosófica dos Direitos Humanos. Florianópolis : Editora da UFSC, 2010, pp. 25-48.

37 PIOVESAN, Flávia. Direitos Humanos e o Direito Constitucional Internacional. 14a. ed. São Paulo: Saraiva, 2013.

38 O Pacto Internacional sobre Direitos Civis e Políticos foi internalizado na ordem jurídica brasileira por meio do Decreto n. 592 de 1992.

39 Em seu preâmbulo, a Declaração destaca a necessidade de construir uma vivência em conjunto que seja harmoniosa e o necessário respeito à pluralidade e às diferentes concepções religiosas, como se vê: "Considérant les diversités religieuse et morale croissantes, au sein des sociétés actuelles, et les défis que rencontrent les États modernes pour favorizes le vivre-ensemble harmonieux; considérant également la necessite de respecter la pluralité des convictions religieuses, athées, agnostiques, philosophiques, et I'obligation de favorizes, par divers moyens, la déliberation démocratique pacifique; considérant enfin que la sensibilité croissante des individus et des peuples aux liberte et aux droits fondamentaux invite les États à veiller à l'équilibre entre les príncipes essentiels qui favorisent le respect de la diversite et l'intégratio de tous les citoyens à la sphère 
BURCKHART, Thiago. Constitucionalismo, Direitos Humanos e Laicidade: Neopentecostalismo e Política no Brasil Contemporâneo. Revista Eletrônica Direito e Política, Programa de Pós-Graduação Stricto Sensu em Ciência Jurídica da UNIVALI, Itajaí, v.13, n.1, $1^{\circ}$ quadrimestre de 2018. Disponível em: www.univali.br/direitoepolitica - ISSN 1980-7791

marco normativo. Esse documento, apesar de não possuir força jurídica vinculante entre Estados, apresenta uma visão geral das reivindicações atuais no que tange à laicidade como princípio fundamental dos Estados de Direito na atualidade. Cabe ressaltar ainda a Declaração de Princípios sobre s Tolerância (UNESCO, 1995), que busca a construção de uma sociedade tolerante e harmoniosa; a Declaração sobre os Direitos das Pessoas Pertencentes a Minorias Nacionais Étnicas, religiosas ou linguísticas (ONU, 1992); além da Declaração sobre a eliminação de todas as formas de intolerância e discriminação fundadas na religião ou nas convicções (ONU, 1981), esta última sendo particularmente específica para o tema da laicidade e liberdade religiosa.

Tomando isso em consideração, os respectivos Estados passaram, sobretudo no mundo ocidental, a positivar o princípio da laicidade em seus respectivos textos constitucionais $^{40}$. A Constituição brasileira de 1988, marco da redemocratização do Estado, prevê em seu art. 19, inciso I, que é vedado à União, Estados, Distrito Federal e Municípios estabelecer cultos religiosos ou igrejas, subvenciona-los, embaraçar-Ihes o funcionamento ou manter com eles, ou seus representantes, relações de dependências ou aliança. Na ordem jurídica brasileira, ao menos formalmente, portanto, está vedada a interferência entre Estado e religião.

O princípio da laicidade está inserido no âmbito da liberdade de pensamento e de expressão, mas com esta não se confunde. A liberdade de expressão e de manifestação do pensamento possui um condão muito mais abrangente que a liberdade de religião, que é uma dimensão que se destaca da própria liberdade de pensamento. Na Constituição brasileira de 1967 não havia previsão expressa de liberdade de religião ${ }^{41}$, apenas de liberdade de consciência. Já a Constituição de

publique, nous, universitaires et citoyens de différent pays, proposons à la réflexions de chacun et au débat public, la declaration suivant".

40 Em grande parte do mundo oriental, entretanto, o secularismo não foi uma característica da era moderna, de modo que em determinados locais como na Índia esta palavra sequer faz parte do rol de categorias políticas. A religião ainda é uma questão central na vida política e social em grande parte destes países, sobretudo nos países muçulmano onde não há uma divisão clara entre política, Estado, religião e vida social. Para aprofundamentos, ver: DEMAND, Peter. O mundo muçulmano. São Paulo : Contexto, 2013.

41 Nesse mesmo sentido, ressalta-se que na história constitucional brasileira, Constituição do Império foi a única que possuía religião oficial. As demais religiões eram permitidas desde que seu culto fosse doméstico (art. $5^{\circ}$ ). 
BURCKHART, Thiago. Constitucionalismo, Direitos Humanos e Laicidade: Neopentecostalismo e Política no Brasil Contemporâneo. Revista Eletrônica Direito e Política, Programa de Pós-Graduação Stricto Sensu em Ciência Jurídica da UNIVALI, Itajaí, v.13, n.1, $1^{\circ}$ quadrimestre de 2018. Disponível em: www.univali.br/direitoepolitica - ISSN 1980-7791

1988 estabelece em seu art. 50, inciso VIII, que ninguém será privado de direitos por motivo de crença religiosa ou convicção filosófica ou política, salvo se as invocar para eximir-se de obrigação legal para todos imposta e recusar-se a cumprir prestação alternativa (escusa de consciência), sendo também considerada no art. 50, inciso VI, como inviolável, sendo assegurado o livre exercício dos cultos religiosos. Nesse sentido,

$\mathrm{Na}$ liberdade de crença entra a liberdade de escolha da religião, a liberdade de aderir a qualquer seita religiosa, a liberdade (ou o direito) de mudar de religião, mas também compreende a liberdade de não aderir a religião alguma, assim como a liberdade de descrença, a liberdade de ser ateu e de exprimir o agnosticismo. Mas não compreende a liberdade de embaraçar o livre exercício de qualquer religião, de qualquer crença, pois aqui também a liberdade de alguém vai até onde não prejudique a liberdade de outro ${ }^{42}$.

Ao estabelecer a laicidade como princípio estruturante da organização do Estado brasileiro, a Constituição de 1988 vai ao encontro das disposições republicanas, podendo haver a colaboração do(s) estado(s) no seu funcionamento desde que seja geral, ou seja, para todas as religiões, e vise a não discriminação entre as diferentes religiões. Cada país, entretanto, estabelece condições diferentes no que tange à laicidade ${ }^{43}$. Em determinados países há a exclusão da religião da esfera pública, já em outros que apesar de serem laicos formalmente, continuam tendo intrínseca relação com a religião dominante em seu contexto.

42 SILVA, José Afonso da. Curso de Direito Constitucional Positivo. 25a ed. São Paulo : Melhoramentos, 2005, p. 249.

43 Apesar de se utilizar neste artigo os termos laicidade e secularização como sinônimos, existe uma divergência na literatura sobre sua diferenciação: "A noção de laicidade, de modo sucinto, recobre especificamente à regulação política, jurídica e institucional das relações entre religião e política, igreja e Estado em contextos pluralistas. Refere-se, histórica e normativamente, à emancipação do Estado e do ensino público dos poderes eclesiásticos e de toda referência e legitimação religiosa, à neutralidade confessional das instituições políticas e estatais, à autonomia dos poderes político e religioso, à neutralidade do Estado em matéria religiosa (ou a concessão de tratamento estatal isonômico às diferentes agremiações religiosas), à tolerância religiosa e às liberdades de consciência, de religião (incluindo a de escolher não ter religião) e de culto. O conceito de secularização, por sua vez, recobre processos de múltiplos níveis ou dimensões, referindo-se a distintos fenômenos sociais e culturais e instituições jurídicas e políticas, nos quais se verifica a redução da presença e influência das organizações, crenças e práticas religiosas". MARIANO, Ricardo. Laicidade à brasileira: católicos, pentecostais e laicos em disputa na esfera pública. Civitas: Revista de Ciências Sociais (Impresso), v. 11, p. 238-258, 2011. 
BURCKHART, Thiago. Constitucionalismo, Direitos Humanos e Laicidade: Neopentecostalismo e Política no Brasil Contemporâneo. Revista Eletrônica Direito e Política, Programa de Pós-Graduação Stricto Sensu em Ciência Jurídica da UNIVALI, Itajaí, v.13, n.1, $1^{\circ}$ quadrimestre de 2018. Disponível em: www.univali.br/direitoepolitica - ISSN 1980-7791

Observa-se, portanto, que no plano normativo houve uma grande evolução aquisitiva no que tange ao reconhecimento da laicidade como fundamento da organização do Estado brasileiro. No plano internacional, apesar dos poucos instrumentos normativos que tratam sobre a matéria - recorda-se que isso se deve à falta de consenso global quanto ao princípio da laicidade - pode-se afirmar que também houve considerável avanço nas últimas décadas. Entretanto, a problemática da laicidade se instaura no momento em que se passa da pura análise da norma jurídica para a análise do contexto em que ela incide.

Como ensina Ricardo Mariano, "a separação Igreja-Estado no Brasil, estabelecida com o advento da República, não pôs fim aos privilégios católicos e nem a discriminação estatal e religiosa às demais crenças, práticas e organizações mágico-religiosas, sobretudo às do gradiente espírita"44. Desse modo, o grande desafio moral, ético e político que se impõe atualmente em matéria de laicidade é entender e professar a laicidade enquanto ordem moral/ética. Essa proposta visa colmar o distanciamento entre a norma e a realidade social e política do Brasil, ainda marcada pela influência da religião.

\section{BANCADA EVANGÉLICA E NEOPENTECOSTALISMO NO BRASIL}

O neopentecostalismo é um movimento religioso que nasceu nos Estados Unidos da América no início do século XX e que passou a se fortalecer em vários "países em desenvolvimento" do Sul do Pacífico, da África, do Leste e do Sudeste da Ásia, sobretudo na América Latina, onde o Brasil se destaca com cerca de 22,5\% de sua população se autodeclarando evangélica ${ }^{45}$. O pentecostalismo, de modo geral, é a segunda maior designação religiosa do Brasil, somente perdendo para os católicos.

O crescimento dos evangélicos não se dá somente em termos demográficos, mas também estende-se pelos campos midiático, assistencial, editorial, de produtos

\footnotetext{
44 MARIANO, Ricardo. Laicidade à brasileira: católicos, pentecostais e laicos em disputa na esfera pública, p. 243.

45 De acordo com os dados do último Censo do IBGE, realizado em 2010. Segundo a pesquisa, entre 2000 e 2010, o total de evangélicos no Brasil subiu de 26,2 milhões para 42,3 milhões. INSTITUTO BRASILEIRO DE GEOGRAFIA E ESTATÍSTICA. Censo 2010. Disponível em: http://censo2010.ibge.gov.br/
} 
BURCKHART, Thiago. Constitucionalismo, Direitos Humanos e Laicidade: Neopentecostalismo e Política no Brasil Contemporâneo. Revista Eletrônica Direito e Política, Programa de Pós-Graduação Stricto Sensu em Ciência Jurídica da UNIVALI, Itajaí, v.13, n.1, $1^{\circ}$ quadrimestre de 2018. Disponível em: www.univali.br/direitoepolitica - ISSN 1980-7791

religiosos, e nos partidos políticos ${ }^{46}$. A relação entre os evangélicos e os partidos políticos, e, portanto, com a política estatal-institucional, foi possível muito recentemente. De acordo com o sociólogo Ricardo Mariano, foi a Assembleia Nacional Constituinte de 1987 que marcou o início "ativismo pentecostal" na política partidária nacional. Nas suas palavras, tratou-se de algo surpreendente, em razão de que

(...) até o início dos anos 1980 os pentecostais se autoexcluíam da política partidária, realçando seu apolitismo com o lema "crente não se mete em política". Até a década de 1970, vigoravam dois comportamentos políticos básicos nesse meio religioso: o dever de votar no governo e, salvo raras exceções, não se envolver com política ${ }^{47}$.

Nesta esteira, Ricardo Mariano afirma que os neopentecostais passaram a ingressar na arena política impelidos por um temor de que a igreja católica estivesse disposta a tentar dilatar seus privilégios junto ao Estado brasileiro na Constituinte, abandonando seu "apolitismo" e buscando formas e meios para garantir seus próprios interesses. Dessa forma,

Os pentecostais abandonaram sua tradicional autoexclusão da política partidária, justificando seu inusitado ativismo político - antes proibitivo, porque tido como mundano e diabólico com a alegação de que urgia defender seus interesses institucionais e seus valores morais contra seus adversários católicos, homossexuais, "macumbeiros" e feministas na elaboração da carta magna. Para tanto, propuseram-se as tarefas de combater, no Congresso Nacional, a descriminalização do aborto e do consumo de drogas, a união civil de homossexuais e a imoralidade, de defender a moral cristã, a família, os bons costumes, a liberdade religiosa e de culto e de demandar concessões de emissoras de rádio e tevê e de recursos públicos para suas organizações religiosas e assistenciais ${ }^{48}$.

Desde então, os evangélicos passaram a se integrar na dinâmica políticoinstitucional brasileira, elegendo a cada eleição um maior número de

46 MARIANO, Ricardo. Expansão pentecostal no Brasil: O caso da Igreja Universal. Estudos Avançados, São Paulo, v. 52, p. 121-138, 2004, p. 121.

47 MARIANO, Ricardo. Laicidade à brasileira, p. 250.

48 MARIANO, Ricardo. Laicidade à brasileira, fl. 251. 
BURCKHART, Thiago. Constitucionalismo, Direitos Humanos e Laicidade: Neopentecostalismo e Política no Brasil Contemporâneo. Revista Eletrônica Direito e Política, Programa de Pós-Graduação Stricto Sensu em Ciência Jurídica da UNIVALI, Itajaí, v.13, n.1, $1^{\circ}$ quadrimestre de 2018. Disponível em: www.univali.br/direitoepolitica - ISSN 1980-7791

representantes não somente no parlamento nacional, mas também nos demais parlamentos estaduais e municipais, bem como no executivo. Seu engajamento político-partidário e institucional levou ainda à criação de um partido próprio, o Partido Republicano Brasileiro (PRB), comandado pela Igreja Universal do Reino de Deus. Mais recentemente, como atesta a socióloga Maria das Dores Campos Machado as vitórias dos evangélicos no Congresso Nacional ocorre em razão de alianças com parlamentares católicos e espíritas ${ }^{49}$.

O dito "ativismo" dos neopentecostais no Brasil em causas de cunho cultural se coloca como um contra movimento à liberalização cultural que ocorre no país desde a década de 1980, mas que se intensifica com o vicejar dos anos 2000, se conformando ao que Terry Eglenton chama de "guerra cultural", na qual duas ou mais perspectivas culturais distintas buscam hegemonia em um mundo marcado pela pluralidade ${ }^{50}$. Nesse sentido, Alain Touraine afirma que os movimentos hodiernos, em grande medida, não possuem mais uma conotação social ou mesmo política, mas assumem reivindicações culturais. Essas reivindicações são em grande medida um contraponto tanto a costumes quanto a ideologias que se perpetuaram ao longo da modernidade e que subjulgaram corpos dos taxados como "diferentes" em termos de gênero, sexualidade, raça e classe social.

Desse modo, o evangelismo ganha força no Brasil como um contraponto a essa "mudança cultural" fruto das reivindicações, prezando por uma volta a uma espécie de valores ligados ao "tradicionalismo". Em seus discursos políticos, é possível se constatar uma repulsa às mudanças culturais, e a tomada de um posicionamento reacionário quanto à elas, apesar de sua heterogeneidade interna. Esse pensamento está calcado numa perspectiva binária e irrefletida sobre a complexidade das relações sociais, bem como num profundo desconhecimento dos processos históricos de libertação. Esse mesmo pensamento é alimentado por aquilo que a filósofa Márcia Tiburi chama de "lacuna política, lacuna ético-política

\footnotetext{
49 BEDINELLI, Talita. Entrevista com Maria das Dores Campos Machado. São Paulo: El País Brasil, 4 dez 2017. Disponível em: <https://brasil.elpais.com/brasil/2017/12/02/politica/1512221378_127760.html>

50 EAGLETON, Terry. A ideia de cultura. Tradução de Sofia Rodrigues. Lisboa: Temas e Debates Editorial, 2003, pp. 73-114.
} 
BURCKHART, Thiago. Constitucionalismo, Direitos Humanos e Laicidade: Neopentecostalismo e Política no Brasil Contemporâneo. Revista Eletrônica Direito e Política, Programa de Pós-Graduação Stricto Sensu em Ciência Jurídica da UNIVALI, Itajaí, v.13, n.1, $1^{\circ}$ quadrimestre de 2018. Disponível em: www.univali.br/direitoepolitica - ISSN 1980-7791

e lacuna cultural"51, alimentada pela ausência de um projeto educacional para o Brasil.

Nesse contexto, a bancada evangélica, que hoje conta com 196 dos 513 deputados, representando 38,20\% dos parlamentares. Somando-os, a bancada evangélica seria hoje o terceiro maior partido da Câmara dos Deputados ${ }^{52}$. Sua composição é bastante heterogênea, com partidos em sua grande maioria do espectro político da direita. Juntamente com os ruralistas, as empreiteiras e os empresários, a bancada evangélica é uma das maiores bancadas do Congresso brasileiro, exercendo larga influência nas decisões políticas do país ${ }^{53}$.

\section{A ATUAÇÃO DA BANCADA EVANGÉLICA NA PEC 181/15 COMO AFRONTA AO PRINCÍPIO DA LAICIDADE}

No dia 8 de novembro de 2017, representantes da bancada evangélica comemoraram a aprovação no âmbito da Comissão Especial do Congresso Nacional da PEC posteriormente conhecida como "PEC do Aborto" por alguns setores, e "PEC da vida" por outros. Sob os coro "Vida Sim, Aborto Não!" encenado pelos representantes da bancada evangélica, o parecer favorável a esta Proposta de Emenda à Constituição foi aprovado por 18 votos contra 1 - de modo que o voto contrário foi da única mulher que participou da Comissão, a deputada federal Érika Kokay - logo após uma manobra de um dos membros da bancada evangélica que é declaradamente contra o aborto. Referida manobra consistiu na alteração da

51 "[...] o pensamento cuidadoso é interpretado em nossa cultura como falta de sucesso. São dois olhares comuns na direção do pensar em nossa época, o da desconfiança e o do descrédito. Aquele que pensa está fora da regra consentida da embriaguez generalizada à qual somos diariamente convidados pelos poderes instaurados" [...] A ausência de um projeto educacional em um país como o Brasil faz parte da produção social da ignorância. A falta de um projeto educacional sério e abrangente levado a cabo por governo e sociedade é uma lacuna política, uma lacuna ético-política e uma lacuna cultural". TIBURI, Marcia. Filosofia Prática: ética, vida cotidiana, vida virtual. Rio de Janeiro : Record, 2014, p. 56-57.

52 MARÉS, Chico. Bancada evangélica seria $3^{\circ}$ partido da Câmara. Curitiba : Gazeta do Povo, 20 abr 2013. Disponível em: < http://www.gazetadopovo.com.br/vida-publica/bancada-evangelicaseria-3-partido-da-camara-e3vwr7to2ezxol996se0xliry>

53 Ressalta-se que a composição parlamentar da legislatura 2015-2018 é considerada por politólogos, sociólogos e juristas como a mais conservadora desde a ditadura militar brasileira (19641985) 
BURCKHART, Thiago. Constitucionalismo, Direitos Humanos e Laicidade: Neopentecostalismo e Política no Brasil Contemporâneo. Revista Eletrônica Direito e Política, Programa de Pós-Graduação Stricto Sensu em Ciência Jurídica da UNIVALI, Itajaí, v.13, n.1, 10 quadrimestre de 2018. Disponível em: www.univali.br/direitoepolitica - ISSN 1980-7791

essência da PEC 181/2015 e da introjeção de conteúdo incompatível com sua redação inicial.

A Proposta de Emenda à Constituição n. 181/2015, apresentada em dezembro de 2015 pelo senador Aécio Neves (PSDB/MG), tem por finalidade primária "alterar o inciso XVIII do art. 70 da Constituição Federal par dispor sobre a licençamaternidade em caso de parto prematuro". De acordo com a proposta, busca-se ampliar os dias de licença-maternidade em caso de nascimento prematuro de bebês, de modo que os dias que o recém-nascido restar no hospital serão adicionados aos 120/180 dias já garantidos pela Constituição, não excedendo, porém, o prazo de 240 dias $^{54}$.

Trata-se de uma proposta que visa ampliar direitos para mulheres no caso específico de nascimento de bebês prematuros. Ocorre que depois de tramitar por todas as comissões internas, quando esta já estava tramitando pela comissão especial responsável pelo seu parecer, o relator desta comissão, por meio de uma manobra política, incluiu duas alterações à PEC, com inclusão de palavras nos arts. $1^{\circ}$ e $5^{\circ}$ da Constituição Federal:

Art. $2^{\circ}$. Dê-se a seguinte redação ao inciso III do art. $1^{0}$ da Constituição Federal:

(...) Art. $1^{\circ}(\ldots)$ III - dignidade da pessoa humana, desde a concepção;

(...) Art. $3^{\circ}$. Dê-se a seguinte redação ao caput do art. $5^{\circ}$ da Constituição Federal: (...) Art. 50. Todos são iguais perante a lei, sem distinção de qualquer natureza, garantindo-se aos brasileiros e aos estrangeiros residentes no país a inviolabilidade do direito à vida desde a concepção, à liberdade, à igualdade, à segurança e à propriedade, nos termos seguintes: (grifou-se).

\footnotetext{
54 A referida PEC se propõe a realizar a seguinte alteração: "Art. 10 O inciso XVIII, do art. 70 da Constituição Federal, passa a vigorar com a seguinte redação: "Art. 70 (...)16 XVIII - licença à gestante, sem prejuízo do emprego e do salário, com a duração de cento e vinte dias, estendendose, em caso de nascimento prematuro, à quantidade de dias que o recém-nascido passar internado, não podendo a licença exceder a duzentos e quarenta dias." CÂMARA DOS DEPUTADOS. PEC $181 / 2015$. Altera o inciso XVIII do art. 70 da Constituição Federal para dispor sobre a licençamaternidade em caso de parto prematuro.
} http://www.camara.gov.br/proposicoesWeb/fichadetramitacao?idProposicao=2075449 
BURCKHART, Thiago. Constitucionalismo, Direitos Humanos e Laicidade: Neopentecostalismo e Política no Brasil Contemporâneo. Revista Eletrônica Direito e Política, Programa de Pós-Graduação Stricto Sensu em Ciência Jurídica da UNIVALI, Itajaí, v.13, n.1, $1^{\circ}$ quadrimestre de 2018. Disponível em: www.univali.br/direitoepolitica - ISSN 1980-7791

As referidas alterações representam retrocessos legislativos diretos para os direitos humanos específicos de mulheres grávidas que desejem realizar o aborto, seja no caso de estupro, risco de morte da mãe ou mesmo anencefalia do feto casos permitidos pelo ordenamento jurídico brasileiro ou por decisão do Supremo Tribunal Federal, no último exemplo. A noção de vida "desde a concepção" representa uma visão cristã de mundo, na qual vai de encontro com as teses científicas que posicionam o início da vida após a formação do cérebro, ou seja, aproximadamente no terceiro mês de gestação. Trata-se da vontade por parte de grupos religiosos cristãos de criminalizar uma prática que é considerada para eles como inaceitável.

No entanto, para além da discussão sobre o conteúdo material do retrocesso legislativo evidente que a PEC anuncia após sua alteração, o que é interessante e significativo analisar em termos políticos, com reflexos no constitucionalismo, é o modo sutil como essa manobra foi realizada, bem como o grau de gravidade que ela representa em termos de conquistas históricas, sendo realizada justamente em uma Proposta de Emenda à Constituição que visava garantir mais direitos às mulheres. A manobra é uma tentativa de interferência descabida no constitucionalismo brasileiro, na medida em que tenta alterar as bases da noção de vida de uma sociedade marcada pela diversidade de perspectivas. Ademais, a manobra não passou por nenhum processo de discussão pública, foi meramente incluída em um texto legislativo que não tinha sequer relação com a proposta de redação inicial.

Em efeito, a manobra evidencia o desrespeito ao princípio da laicidade, consagrado pela Constituição brasileira. É notória a incompreensão do dispositivo da laicidade por uma grande gama de sujeitos e representantes políticos, o que abre caminho para a sutilidade que grupos religiosos se infiltram na política e buscam impor sua moral. A atitude de membros da bancada evangélica vai de encontro com as aquisições evolutivas do constitucionalismo democrático em todo o globo. A atitude vai de encontro ao princípio da democracia, que se manifesta no respeito às regras do jogo e na abertura de canais de diálogo com sujeitos que serão diretamente atingidos por esta decisão. A atitude desrespeita as liberdades fundamentais de 
BURCKHART, Thiago. Constitucionalismo, Direitos Humanos e Laicidade: Neopentecostalismo e Política no Brasil Contemporâneo. Revista Eletrônica Direito e Política, Programa de Pós-Graduação Stricto Sensu em Ciência Jurídica da UNIVALI, Itajaí, v.13, n.1, $1^{\circ}$ quadrimestre de 2018. Disponível em: www.univali.br/direitoepolitica - ISSN 1980-7791

mulheres de terem o domínio sobre seu próprio corpo e o poder de decidir se desejam ou não realizar o aborto.

Os atos reverberam uma "política fundamentalista" que opera por meio do "pânico moral"55, a instrumentalização do medo em diversas instâncias sociais e políticas, tendo por objetivo a negação de pautas de reivindicações "feministas". A noção patriarcal de "família" é o conceito-chave desta operação ideológica, de modo que qualquer política pública reconhecida para o fortalecimento das demandas das mulheres - ou dos grupos LGBT - pudesse representar uma negação ao valor da "família"56.

Em efeito, a referida PEC ainda necessita ser discutida e votada pelo plenário da Câmara dos Deputados e do Senado Federal. Em caso de aprovação, ela ainda poderá ser alvo de Ação Direta de Inconstitucionalidade (ADI) a ser impetrada no Supremo Tribunal Federal. No entanto, trata-se de um caso significativo para analisar a interferência de correntes religiosas no constitucionalismo brasileiro contemporâneo, evidenciando uma afronta ao princípio da laicidade. Mesmo sendo este um princípio que funda a modernidade e o constitucionalismo, ainda buscase a sua real e prometida aplicação. Ainda é necessário construir caminhos, meios, técnicas, espírito e vontade de constituição, como dizia Konrad Hesse ${ }^{57}$, para concretizar a laicidade prometida.

\section{CONSIDERAÇÕES FINAIS}

Uma análise comprometida com a realidade social e política brasileira certamente concluirá que em muitos aspectos há um claro distanciamento ente normatividade e facticidade. No que se refere à laicidade, entendida aqui como um direito positivado na Constituição Federal, não é diferente. Esta constatação, entretanto, não deve ser de cunho fatalista, mas deve servir de impulso para a vontade de

\footnotetext{
55 VITAL DA CUNHA, Christina; LOPES, Paulo Victor Leite. Religião e Política: uma análise da atuação de parlamentares evangélicos sobre direitos das mulheres e de LGBTs no Brasil. Rio de Janeiro: Fundação Heinrich Böll, 2012.

56 PEREIRA, Edilson. Poder e medo: os evangélicos na política e o combate à agenda feminista. Religião e Sociedade, Rio de Janeiro, vol. 33, n. 1, 2013.

57 HESSE, Konrad. A força normativa da Constituição. Brasília : IBDC, 2010.
} 
BURCKHART, Thiago. Constitucionalismo, Direitos Humanos e Laicidade: Neopentecostalismo e Política no Brasil Contemporâneo. Revista Eletrônica Direito e Política, Programa de Pós-Graduação Stricto Sensu em Ciência Jurídica da UNIVALI, Itajaí, v.13, n.1, $1^{\circ}$ quadrimestre de 2018. Disponível em: www.univali.br/direitoepolitica - ISSN 1980-7791

Constituição, como dizia Konrad Hesse, ou seja, para (re)inventar a ação política - pública - que lhe possa fazer valer e surtir efeitos empiricamente. Trata-se de um desafio cuja responsabilidade é coletiva, e que perpassa pela prática de uma ética constitucional, um caminho aberto para a imaginação, a criação e a arte.

Além disso, a prática empírica também demonstra a necessidade de pensar e estruturar mecanismos legislativos e judiciais que prezem pela "representação conforme a Constituição". Há a necessidade de se readequar o sentido o "mandato político", pensando-o como um instrumento da democracia para a concretização e aprofundamento da própria democracia. Isso, evidentemente, implica na concretização dos direitos fundamentais previstos na Constituição, bem como da ideia de Estado laico. Esses instrumentos podem servir de sansões educativas aos representantes políticos que não assumam o papel de agirem conforme a Constituição e em prol da efetivação deste documento.

A situação que se evidencia neste artigo demostra a necessidade de pensar em mecanismos, tanto educativos quanto de outra natureza, para que o Estado Democrático de Direito seja realizável em sua práxis. A promessa da laicidade, edificada ao longo da modernidade ocidental, não pode ficar à mercê da manipulação de grupos de interesse nas instituições representativas. A confusão entre religião e Estado traz consigo a possibilidade de retrocessos significativos em matéria de direitos humanos, sobretudo aos grupos sociais que foram historicamente marginalizados do processo de construção de decisões políticas. O empoderamento destes grupos, sua ascensão à esfera política e a tomada de consciência da sociedade podem ser meios também para a garantia da laicidade.

A laicidade não deve ser somente uma promessa. Ela deve ser um dos pilares fundantes de qualquer sociedade plural e de qualquer política legitimamente democrática. 
BURCKHART, Thiago. Constitucionalismo, Direitos Humanos e Laicidade: Neopentecostalismo e Política no Brasil Contemporâneo. Revista Eletrônica Direito e Política, Programa de Pós-Graduação Stricto Sensu em Ciência Jurídica da UNIVALI, Itajaí, v.13, n.1, $1^{\circ}$ quadrimestre de 2018. Disponível em: www.univali.br/direitoepolitica - ISSN 1980-7791

\section{REFERÊNCIA DAS FONTES CITADAS}

ACKERMAN, Bruce. The rise of world constitutionalism. Yale Law School, 1997.

ARANHA, Maria Lúcia de Arruda; MARTINS, Maria Helena Pires. Temas de Filosofia. Editora Moderna : São Paulo, 2005.

ARENDT, Hannah. Sobre a revolução. São Paulo : Companhia das Letras, 2011.

BARROSO, Luís Roberto. Ação Direta de Inconstitucionalidade 4.439/DF (Voto). Tribunal Pleno do Supremo Tribunal Federal, 2016.

BEDINELLI, Talita. Entrevista com Maria das Dores Campos Machado. São Paulo : El País Brasil, 4 dez 2017.

BOBBIO, Norberto. A era dos direitos. Rio de Janeiro : Elsevier, 2004.

BOBBIO, Norberto; MATTEUCCI, Nicolà; PASQUINI, Gianfranco. Dicionário de Política. Vol I. $11^{a}$ Ed. Brasília : Editora Universidade de Brasília, 1998.

BURCKHART, Thiago. Direito, Cultura e Cidadania. Curitiba : Prismas, 2017.

CÂMARA DOS DEPUTADOS. PEC 181/2015. Altera o inciso XVIII do art. 70 da Constituição Federal para dispor sobre a licença-maternidade em caso de parto prematuro.

http://www.camara.gov.br/proposicoesWeb/fichadetramitacao?idProposicao=207 5449

CANÇADO TRINDADE, Antônio Augusto. Tratado de Direito Internacional dos Direitos Humanos. Vol I ,Porto Alegre : Sergio Fabris Editor, 2003.

CANOTILHO, José Joaquim Gomes. Direito Constitucional e Teoria da Constituição. 7a Ed. Coimbra : Almedina, 2011.

CHAUÍ, Marilena. Filosofia. São Paulo : Editora Ática, 2008.

DEMAND, Peter. O mundo muçulmano. São Paulo : Contexto, 2013.

DIMOULIS, Dimitri. Manual de Introdução do Direito. $3^{a}$ Ed. São Paulo : Editora Revista dos Tribunais, 2010.

DULCE, Maria José Fariñas. Democracia y pluralismo: una mirada hacia la emancipación. Madrid : Dykinson, 2014.

DUSSEL, Enrique. 1492. El encubrimiento del otro: hacie el orígen del mito de la modernidad. La Paz : CLACSO, 1994.

EAGLETON, Terry. A ideia de cultura. Tradução de Sofia Rodrigues. Lisboa : Temas e Debates Editorial, 2003. 
BURCKHART, Thiago. Constitucionalismo, Direitos Humanos e Laicidade: Neopentecostalismo e Política no Brasil Contemporâneo. Revista Eletrônica Direito e Política, Programa de Pós-Graduação Stricto Sensu em Ciência Jurídica da UNIVALI, Itajaí, v.13, n.1, $1^{\circ}$ quadrimestre de 2018. Disponível em: www.univali.br/direitoepolitica - ISSN 1980-7791

FERREIRA, António Matos. Laicismo ideológico e laicidade: entre a ideia de tolerância e a tentação totalitária. Revista Theologica, 2a série, n. 39, v. 2, 2004.

GAADER, Jostein; HELLERN, Victor; NOTAKER, Henry. O livro das religiões. 7a Ed. Tradução de Isa Mara Lando. São Paulo : Companhia das Letras, 2000.

GIUMBELLI, Emerson. Religião, Estado, modernidade: notas a propósito de fatos provisórios. Estudos Avançados USP. São Paulo, v. 52, n. 52, 2004.

GOYARD-FABRE, Simone. Os fundamentos da ordem jurídica. São Paulo : Martins Fontes, 2002.

HABERMAS, Jürgen. Direito e Moral. Tradução de Sandra Luppert. Instituto Piaget: Lisboa, 1992.

HESSE, Konrad. A força normativa da Constituição. Brasília : IBDC, 2010.

INSTITUTO BRASILEIRO DE GEOGRAFIA E ESTATÍSTICA. Censo 2010. Disponível em: http://censo2010.ibge.gov.br/

KELSEN, Hans. Teoria pura do direito. São Paulo: Revista dos Tribunais, 2a ed., 2002.

MARÉS, Chico. Bancada evangélica seria $3^{\circ}$ partido da Câmara. Curitiba: Gazeta do Povo, 20 abr 2013.

MARIANO, Ricardo. Neopentecostais: sociologia do novo pentecostalismo no Brasil. Ed. Loyola: São Paulo, 2005.

MARIANO, Ricardo. Laicidade à brasileira: católicos, pentecostais e laicos em disputa na esfera pública. Civitas: Revista de Ciências Sociais (Impresso), v. 11, p. 238-258, 2011.

MARIANO, Ricardo. Expansão pentecostal no Brasil: O caso da Igreja Universal. Estudos Avançados, São Paulo, v. 52, p. 121-138, 2004.

MOUFFE, Chantal. El retorno de lo político: comunidade, ciudadanía, pluralismo, democracia radical. Barcelona : Ediciones Paidós Ibérica, 1999.

NIETZSCHE, Friedrich. Genealogia da moral: uma polêmica. Tradução, notas e posfácio de Paulo César de Souza. São Paulo : Companhia das Letras, 2009.

NUSSBAUM, Martha. Liberty of conscience: in defense of America's tradition of religious equality. Cambridge : Harvard University Press, 2008.

PEREIRA, Edilson. Poder e medo: os evangélicos na política e o combate à agenda feminista. Religião e Sociedade, Rio de Janeiro, vol. 33, n. 1, 2013.

PINZANI, Alessandro. A cara de Janus dos direitos humanos: os direitos humanos entre política e moral. In. LUNARDI, Giovanni; SECCO, Marcio (Orgs.). 
BURCKHART, Thiago. Constitucionalismo, Direitos Humanos e Laicidade: Neopentecostalismo e Política no Brasil Contemporâneo. Revista Eletrônica Direito e Política, Programa de Pós-Graduação Stricto Sensu em Ciência Jurídica da UNIVALI, Itajaí, v.13, n.1, $1^{\circ}$ quadrimestre de 2018. Disponível em: www.univali.br/direitoepolitica - ISSN 1980-7791

Fundamentação Filosófica dos Direitos Humanos. Florianópolis : Editora da UFSC, 2010.

PIOVESAN, Flávia. Direitos Humanos e o Direito Constitucional Internacional. 14a. ed. São Paulo: Saraiva, 2013.

PORTIER, Philippe. Nouvelle modernité, nouvelle laicité. La Republique française face ao religieux (1880-2009). Estudos de Religião, v. 25, n. 41, jul-dez 2011.

RODOTÀ, Stefano. Diritto e giustizia: interroghiamo la Costituzione. Napoli : La Scuola do Pitagora editrice, 2016.

ROSAS, Nina. O desenvolvimento do neopentecostalismo brasileiro. In: XI Simpósio Nacional da Associação Brasileira de História das Religiões. Goiânia, 2009.

SAID, Edward. Orientalismo: o oriente como invenção do ocidente. São Paulo : Companhia das Letras, 1990.

SANTOS, Boaventura de Sousa. Pelas mãos de Alice: o social e o político na pósmodernidade. 7a Ed. Porto : Afrontamentos, 1999.

SILVA, José Afonso da. Curso de Direito Constitucional Positivo. 25a ed. São Paulo : Melhoramentos, 2005.

TOURAINE, Alain. O que é democracia? Tradução de Guilherme João de Freitas Teixeira. Petrópolis : Editora Vozes, 1996.

TOURAINE, Alain. Poderemos viver juntos? Iguais e diferentes. Tradução de Jaime Al. Clasen e Ephrim F. Alves. Petrópolis : Editora Vozes, 1999.

VITAL DA CUNHA, Christina; LOPES, Paulo Victor Leite. Religião e Política: uma análise da atuação de parlamentares evangélicos sobre direitos das mulheres e de LGBTs no Brasil. Rio de Janeiro: Fundação Heinrich Böll, 2012.

WEBER, Max. Economia e sociedade. Vol I. $4^{\text {a }}$ Ed. Brasília : Editora da Universidade de Brasília, 2000.

Submetido em: 27/12/2018

Aprovado em: 18/04/2018 